\title{
Traditional food preparation of wild edible vegetables among the ethnic groups of Mizoram, North East India
}

\author{
Rosie Lalmuanpuii ${ }^{1}$, Betsy Zodinpuii ${ }^{2}$, J. Lalbiaknunga ${ }^{1}$ and Zothanpuia ${ }^{3^{*}}$ (D)
}

\begin{abstract}
Exploration of ethnic traditional food recipes has an immense contribution to the preservation and sustainability of traditional food habits and culture. The main objective of this study was to explore and document traditional food recipes prepared from wild edible vegetables among two ethnic groups of Mizoram, Northeast India. The method employed for this study was mainly based on a household survey; randomly selected 35 households in Aizawl district representing the major ethnic groups, namely Hmar and Paihte. Information was collected on different types of wild edible vegetables ethnic food, as prepared and consumed by the local people. Twenty-four types of traditional food recipes were documented according to their seasonal availability, and the affinities of choices in food consumption are comparable among the two ethnic groups. It was also reported that wild edible vegetables play a significant role in safeguarding food security and improve nutrition in diets. The present work documents the wild edible vegetables used traditionally by two ethnic groups of Mizoram for various recipes and highlights the necessity of conserving such traditional knowledge besides throwing light on their economic potential. The study suggests that future investigation be carried out to evaluate the nutritional and bioactive properties of wild edible vegetables.
\end{abstract}

Keywords: Wild edible vegetables, Traditional food recipes, Ethnic communities, Aizawl district, Mizo

\section{Introduction}

Knowledge of traditional foods from the wild and their preparations have been transferred verbally among the indigenous people [1]. Wild edible vegetables (WEVs) define plant resources that are harvested directly from the wild for the benefit of human consumption [2, 3]. Wild edible plants provide food not only in times of food shortages but also in normal times. These wild foods add unique tastes, providing important essential biochemicals, which help in maintaining the proper functioning of the human body $[4,5]$. Globally, around one billion people use WEVs daily as a source of food [6]. Since WEVs

*Correspondence: zothanpuia@pucollege.edu.in; jpahnamte6@gmail.com

${ }^{3}$ Department of Biotechnology/Life Sciences, Mizoram University, Pachhunga University College Campus, Aizawl, Mizoram 796001, India

Full list of author information is available at the end of the article are easily available and freely accessible from their natural habitats, many ethnic people gain knowledge on how to gather WEVs and their preparation [7]. Wild edible resources are generally collected on a seasonal basis and are often stored after processing either by cooking, drying, or fermenting. The North Eastern Region of the Indian subcontinent has an enormous reserve of traditional fermented foods owing to its rich ethnic diversity and also due to the availability of surplus bioresources in the region. There are $94.7 \%$ of the tribal people living in Mizoram state and traditional knowledge provides them food, a health care system, and shelter [8]. There are seven major tribes of Mizo living within Mizoram such as Hmar, Paihte, Pawi, Ralte, Lai, Mara, and Lusei [9]. Among these, three major tribal groups such as Paihte, Hmar, and Lusei reside within the Aizawl district original author(s) and the source, provide a link to the Creative Commons licence, and indicate if changes were made. The images or other third party material in this article are included in the article's Creative Commons licence, unless indicated otherwise in a credit line to the material. If material is not included in the article's Creative Commons licence and your intended use is not permitted by statutory regulation or exceeds the permitted use, you will need to obtain permission directly from the copyright holder. To view a copy of this licence, visit http://creativecommons.org/licenses/by/4.0/. 
having more or less similar methods of traditional food preparations.

Rice is the staple food of tribal groups of Mizoram and is taken along with vegetables, salads, and meats. Shifting cultivation is the main method of traditional agriculture in Mizoram which is still practiced in highland till date, supporting the livelihood of the state by providing conventional food [10]. However, conventional crops do not meet the requirements of the people; traditional recipes from WEVs are still trending among local people during the available season. Vegetables are seldom imported from other districts where forest-based WEVs are the main source of vegetables, especially among Hmar and Paihte tribes. Traditional Mizo foods are mainly prepared in boiled, smoked, and fermented form, and spices are rarely used as compared to other Indian cuisines [8]. The typical Mizo popular dishes include bai (mixed vegetables combined with fermented pork fat) and tlak/mung (simply boiled form). The use of cooking oil in food preparations was never known to the general ethnic group in the past. However, with the introduction of Christianity by the British missionary in the 1890 s to the people of Mizoram, the mode of food preparation has been improved tremendously [11]. A wide range of food habits found worldwide differs from different ethnic groups, and a unique traditional food processing technique practiced by the ethnic communities of Mizoram has been discussed [11]. Production of fermented food and beverages is highly popular, has been traditionally inherited, and also constitutes an essential component of the daily diet of the Mizo people [12]. The traditional food processing and preparations were previously reported by several authors globally [13-15] and also were found from northeast India such as Manipur [5, 16, 17], Tripura, [18], Sikkim $[19,20]$. However, the cuisine exploration for the selected traditional WEVs has never been reported so far and is presented here in the first-ever report which will be useful for future references.

\section{Methodology}

\section{Study area and sites}

Mizoram is the fifth smallest state in India having an area of $21,087 \mathrm{~km}^{2}$, the Tropic of Cancer runs through the state closely at its middle. It is a mountainous region with heavy rainfall of $\sim 2500 \mathrm{~mm}$ annually. Mizoram is richly endowed by nature with great diversity of WEVs, timber yielding plants and medicinal plants. Moreover, Mizoram has an abundant natural bamboo resource and approximately $57 \%$ of the geographical area of the state is under bamboo cover. In terms of the percentage of forest cover of the total geographical area, Mizoram has the highest forest cover in India (85.41\%). Within Mizoram, the present study was confined to Aizawl district, Northeast
India (Fig. 1). It has geo-coordinates of $24^{\circ} 25^{\prime} 16.04^{\prime \prime}$ to $23^{\circ} 18^{\prime} 17.78^{\prime \prime} \mathrm{N}$ latitudes and $92^{\circ} 37^{\prime} 03.27^{\prime \prime}$ to $93^{\circ} 11^{\prime} 45.69^{\prime \prime}$ E longitudes with an elevation of $1132 \mathrm{~m}$ above sea level $(3714 \mathrm{ft})$ [21]. The total geographical area of the district is $3576.31 \mathrm{~km}^{2}$ and accounts for $16.96 \%$ of the total geographical area of the state. Topographically, the district comprises agricultural plains, hilly terrains, and rich bioresources [22]. It received a direct influence of both the northeast and southwest monsoon with humid and moderate tropical climatic conditions. It primarily has four seasons: Winter (December-February) with temperature ranging between 10 and $22{ }^{\circ} \mathrm{C}$, Summer (MarchMay) with temperature between 19 and $30^{\circ} \mathrm{C}$, Monsoon (June-August) with an average temperature of $20-30{ }^{\circ} \mathrm{C}$, and Autumn (September-November) with temperature between 18 and $30{ }^{\circ} \mathrm{C}$. According to India State of Forest report 2015, Aizawl district has an area of $28 \mathrm{~km}^{2}$ (0.78\%) very dense forest, $1135 \mathrm{~km}^{2}$ (31.745) of moderately dense forest and an area of $2022 \mathrm{~km}^{2}$ (56.55\%) of open forest. According to the genetic system or major soil group classification, soils of Aizawl district fall under red and lateritic soils.

\section{Ethnic groups}

The ethnic diversity of the Aizawl district was found interesting as evidenced by three different tribal groups. Of these, two groups were selected to document their traditional recipes, based on the degree of traditionalism of the people and local dependency on forest and natural resources. Moreover, they were the dominant group and lived in a distinct village, namely Phuaibuang which is about $170 \mathrm{~km}$ away and N.E Tlangnuam which is $187 \mathrm{~km}$ away from Aizawl of the Aizawl district (Fig. 2). The major ethnic tribe of N.E Tlangnuam village is 'Paihte.' According to the 2011 census of Mizoram, it has a population of 658 with 318 males and 340 females resided in 97 households. In Phuaibuang village, the major ethnic tribe is 'Hmar.' It has a population of 2134 (1087 male and 1047 female) with 398 households, having a distinct language of their own.

\section{Exploration of traditional food recipe}

Field survey was conducted once a month during January to December, 2018, because the seasonal availability of WEVs used in the recipes differs as mentioned in Table 1. The method used for this study was a random household survey [23] following insight observation among the two tribal groups from the two villages of the Aizawl district. A total of 35 households (14 from Paihte and 21 from Hmar communities) were visited during the field survey. In this study, the data were obtained with the help of volunteers from the respective villages. The method of preparation of WEVs as the cuisine was documented through 


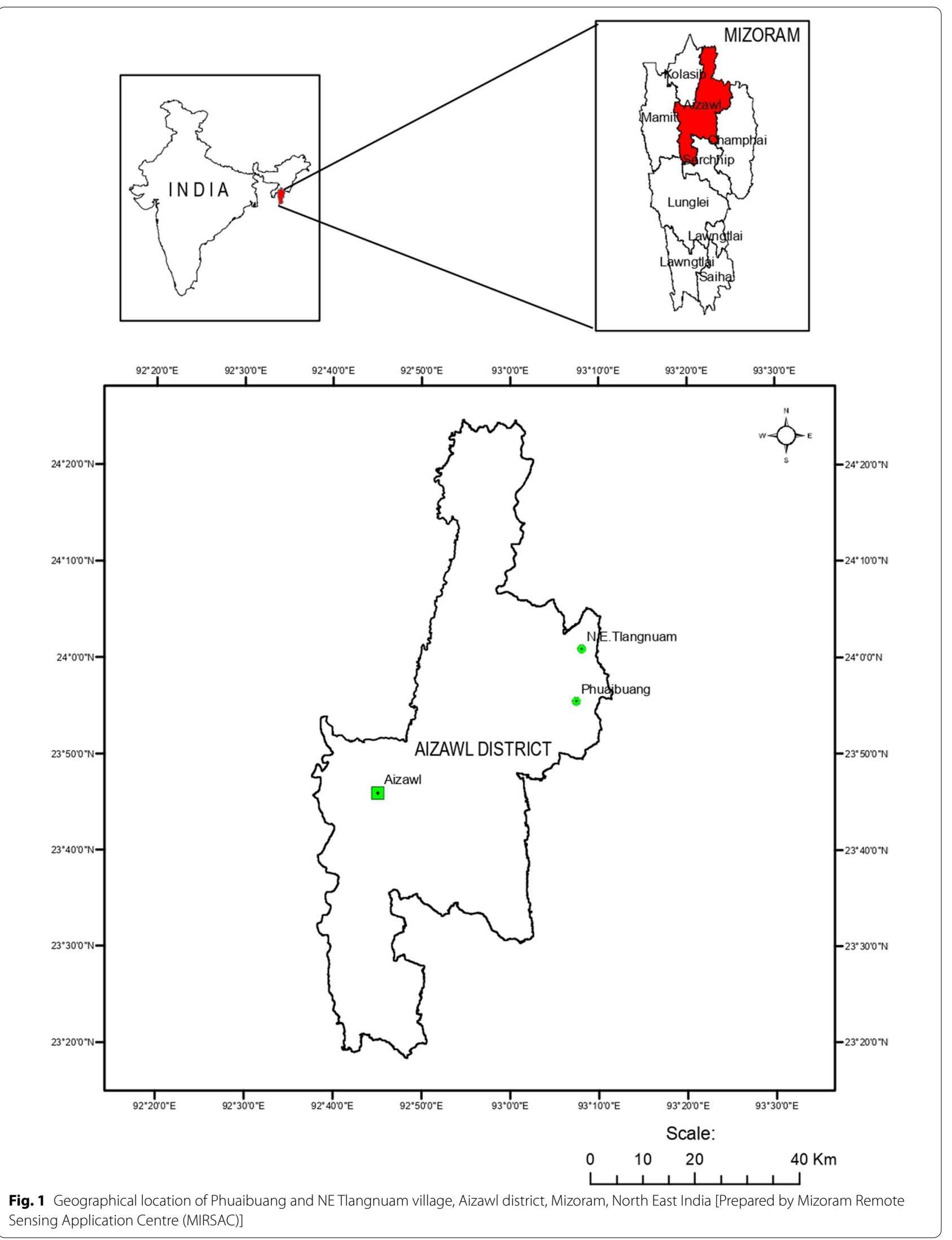



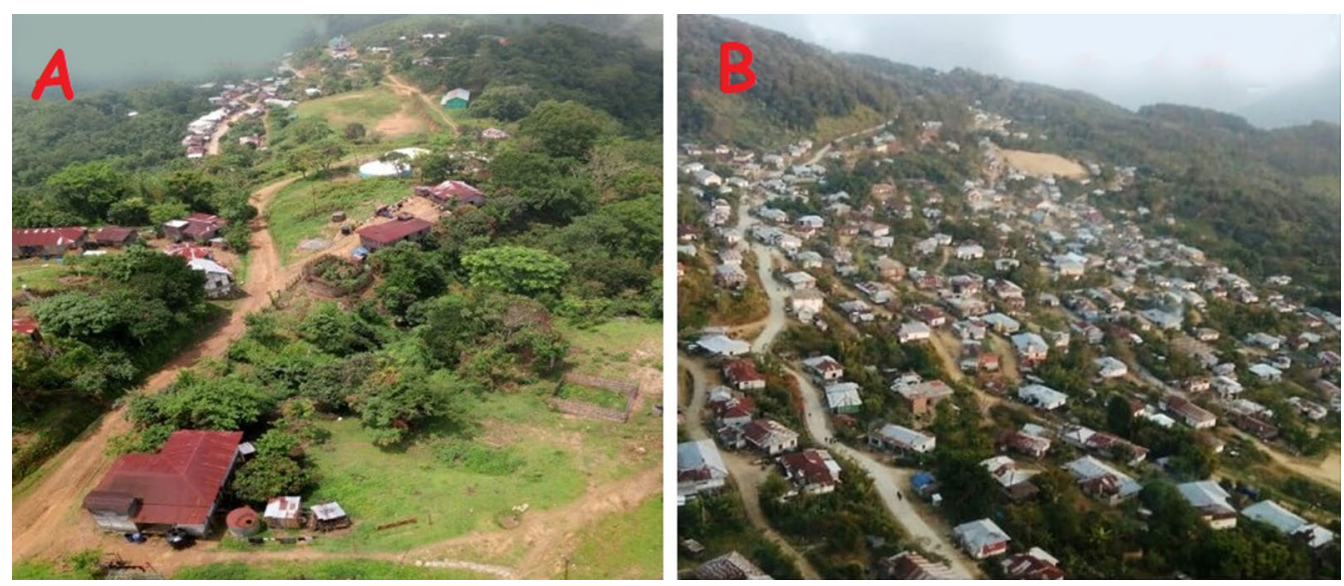

Fig. 2 Visual representation of the study sites A N.E Tlangnuam village; B Phuaibuang village

interviews. Since the two ethnic groups speak a distinct language, the names of the local dishes, and methods of preparation were recorded in their language and translated into 'Mizo' with the help of a language translator. The responses documented in Mizo language by the volunteers were translated in English by the authors. The entire documented recipes were photographed, and the description is given in English.

\section{Results}

During the field survey, twenty-four (24) types of traditional food recipes consumed by two ethnic groups of Aizawl district, Mizoram were documented according to their seasonal availability. A diverse group of WEVs that comprises of 19 families were documented. The life-form depicted that tree were dominating (11 species) followed by herbs ( 6 species), two species each of shrub, bamboo, climber, and one species of palm. The leaves and shoots were the most frequently used parts of the plant for the preparation of various traditional recipes. WEVs were readily available for consumption throughout the year and the majority of them were harvested by the local people mostly during the rainy season (April to September). Out of 24 species of WEVs documented, 16 species were of ethno medicinally importance (Table 1 ). The results further showed that the affinities of choices in food consumption were more or less similar among the two ethnic groups. Some of the recipes had a complex method of preparation with several traditional seasonings added to them. It is important to note that several of these cuisines have been commercialized in local restaurants and hotels. The serving size of the traditional recipes documented in this study was calculated for five individuals and prepared accordingly.

\section{(1) Antumbu Mung}

Mung is the simplest way of cuisine preparation among Hmar and Paihte communities (Fig. 3A). Antumbu (Brassaiopsis hainla) is the main ingredient for this recipe. It is the most prominent dish among Hmar and Paihte in the study area. The mode of preparation is simple, about $500 \mathrm{~g}$ of young shoots and leaves were simply boiled for 15-30 min; the water is then discarded and the dish is ready to be served. For a better taste, dried chilies and salt are normally added.

\section{(2) Chartang}

Chartang is a traditional dry meat-based recipe of Hmar tribe and is the most popular and delicious food. Approximately $1 \mathrm{~kg}$ of dry meat is first cooked for 10-15 min in a pressure cooker, after this, an appropriate amount $(\sim 100 \mathrm{~g})$ of fresh leaves or dry leaves of Sihzo (Eurya acuminata) is added along with salt and two teaspoons of chingal (ash filtrate/lye) followed by the addition of a few drops of saum/ sathu (fermented pork fat). All the contents are mixed thoroughly, and it is ready to be served. Eurya acuminata is the main ingredient in this recipe and is also highly preferred for making another recipe (Fig. 3B).

\section{(3) Theibal chhum}

This recipe can be prepared only when fish is available. To prepare, $500 \mathrm{~g}$ of the dry or fresh fish is boiled with the tender leaves of Ficus auriculata $(\sim 500 \mathrm{~g})$ and an appropriate amount of salt is added to it (Fig. 3C). For better taste, crushed onion, garlic, ginger, and wild coriander are also added as per one's wish. 
Table 1 Lists of wild edible vegetables used for the preparation of traditional recipe

\begin{tabular}{|c|c|c|c|c|c|c|c|c|}
\hline SL/No & Plant name & Family & Local name & Common name & Habit & Edible parts & $\begin{array}{l}\text { Seasonal } \\
\text { availability }\end{array}$ & $\begin{array}{l}\text { Ethnomedicinal } \\
\text { value }\end{array}$ \\
\hline 1 & $\begin{array}{l}\text { Brassaiopsis } \\
\text { hainla (Buch. } \\
\text {-Ham.) Seem }\end{array}$ & Araliaceae & Antumbu & Chuletro & Tree & $\begin{array}{l}\text { Leaves and } \\
\text { shoot }\end{array}$ & Apr-Sep & \\
\hline 2 & $\begin{array}{l}\text { Eurya acuminata } \\
\text { DC }\end{array}$ & $\begin{array}{l}\text { Pentaphy- } \\
\text { lacaceae }\end{array}$ & Sihzo & $\begin{array}{l}\text { Tapering Leaf } \\
\text { Eurya }\end{array}$ & Tree & Leaves & Whole Year & - \\
\hline 3 & $\begin{array}{l}\text { Ficus auriculata } \\
\text { Lour }\end{array}$ & Moraceae & Theibal & $\begin{array}{l}\text { Elephant year } \\
\text { fig tree }\end{array}$ & Tree & Leaves & Whole Year & - \\
\hline 4 & $\begin{array}{l}\text { Fagopyrum tatari- } \\
\text { cum (L.) Gaertn }\end{array}$ & Poligonaceae & Anbawng & Buckwheat & Herb & Leaves & Mar-Sep & $\begin{array}{l}\text { Gynecological } \\
\text { problem }\end{array}$ \\
\hline 5 & $\begin{array}{l}\text { Amomum deal- } \\
\text { batum Roxb }\end{array}$ & Zingiberaceae & Aihritil & Black cardamom & Herb & Flower bud & Jan-Apr & Sleep inducer \\
\hline 6 & $\begin{array}{l}\text { Senegalia pen- } \\
\text { nata (L.) }\end{array}$ & Fabaceae & Khanghmuk & Climbing wattle & Climber & Tender leaves & Mar-Jun & Food poisoning \\
\hline 7 & $\begin{array}{l}\text { Marsdenia macu- } \\
\text { lata Hook }\end{array}$ & Apocyanaceae & Ankhapui & Masculatus & Climber & $\begin{array}{l}\text { Leaves and } \\
\text { shoot }\end{array}$ & Whole Year & Hypertension \\
\hline 8 & $\begin{array}{l}\text { Rhynchotechum } \\
\text { ellipticum (Wall. } \\
\text { exD. Dietr.) A. DC }\end{array}$ & Gesneriaceae & Tiarrhep & $\begin{array}{l}\text { Taiwan Rhyncho- } \\
\text { techum }\end{array}$ & Shrub & Leaves & Apr-Aug & Anti-cancer \\
\hline 9 & $\begin{array}{l}\text { Ensete superbum } \\
\text { (Roxb.) Chees- } \\
\text { man }\end{array}$ & Musaceae & Saisu & Rock banana & Herb & Pseudo stem & Whole Year & $\begin{array}{l}\text { Snake bite, Con- } \\
\text { vulsion }\end{array}$ \\
\hline 10 & $\begin{array}{l}\text { Solanum anguivi } \\
\text { Lam }\end{array}$ & Solanaceae & Tawkte & $\begin{array}{l}\text { Indian night } \\
\text { shade }\end{array}$ & Shrub & Fruits & Apr-Jul & Anti-septic, boils \\
\hline 11 & $\begin{array}{l}\text { Meloccana baccif- } \\
\text { era (Roxb.) Kurz }\end{array}$ & Poaceae & Mautak & Berry bamboo & Bamboo & Shoots & Apr-Sep & - \\
\hline 12 & $\begin{array}{l}\text { Aganope thyrsifo- } \\
\text { lia (Benth.) Polhill }\end{array}$ & Fabaceae & Hulhu & Flame Tree & Tree & $\begin{array}{l}\text { Young leaves } \\
\text { and shoots }\end{array}$ & Feb-Apr & - \\
\hline 13 & $\begin{array}{l}\text { Caryota mitis } \\
\text { Lour }\end{array}$ & Arecaceae & Meihle & Fishtail palm & Palm & Tender shoots & Whole Year & - \\
\hline 14 & $\begin{array}{l}\text { Musa balbisiana } \\
\text { Colla }\end{array}$ & Musaceae & Tumbu & Wild banana & Bamboo & Inflorescence & Whole Year & $\begin{array}{l}\text { Dysentery, snake } \\
\text { bites }\end{array}$ \\
\hline 15 & $\begin{array}{l}\text { Aralia dasyphylla } \\
\text { Miq }\end{array}$ & Araliaceae & Hlingthufir & Spikenard & Tree & $\begin{array}{l}\text { Tender Leaves } \\
\text { and shoots }\end{array}$ & Mar-Aug & Nerve problem \\
\hline 16 & Centella asiatica L & Umbelliferae & Lambak & $\begin{array}{l}\text { Indian pen- } \\
\text { nywort }\end{array}$ & Herb & Whole plants & Apr-Oct & $\begin{array}{l}\text { Anti-diabetic, } \\
\text { hypertension }\end{array}$ \\
\hline 17 & $\begin{array}{l}\text { Dysoxylum excel- } \\
\text { sum Blume }\end{array}$ & Meliaceae & Thingthupui & NA & Tree & $\begin{array}{l}\text { Leaves and } \\
\text { shoots }\end{array}$ & Apr-Sep & $\begin{array}{l}\text { Dysentery, Stom- } \\
\text { ach problem }\end{array}$ \\
\hline 18 & $\begin{array}{l}\text { Wendlandia } \\
\text { budleioides Wall }\end{array}$ & Rubiaceae & Batling & NA & Tree & Flower bud & Feb-April & \\
\hline 19 & $\begin{array}{l}\text { Parkia timoriana } \\
\text { (DC.) Merr }\end{array}$ & Fabaceae & Zawngtah & Tree bean & Tree & $\begin{array}{l}\text { Fruits and flower } \\
\text { head }\end{array}$ & Oct-Apr & $\begin{array}{l}\text { Indigestion, Anti- } \\
\text { diarrheal }\end{array}$ \\
\hline 20 & $\begin{array}{l}\text { Trevesia palmata } \\
\text { (Roxb.ex Lindl.) } \\
\text { Vis }\end{array}$ & Araliaceae & Kawhtebel & Snowflake plant & Tree & Flower bud & Feb-April & Anti-diabetic \\
\hline 21 & $\begin{array}{l}\text { Amaranthus } \\
\text { viridis L }\end{array}$ & Amaranthaceae & Lenhling & Wild amaranth & Herb & $\begin{array}{l}\text { Tender shoots } \\
\text { and leaves }\end{array}$ & Apr-Sep & $\begin{array}{l}\text { Snake bite, kidney } \\
\text { problem }\end{array}$ \\
\hline 22 & $\begin{array}{l}\text { Gnetum gnemon } \\
\mathrm{L}\end{array}$ & Gnetaceae & Pelh & Joint-fir spinach & Tree & leaves & Jun-Sep & \\
\hline 23 & $\begin{array}{l}\text { Oroxylum indi- } \\
\text { cum (L.) Kurz }\end{array}$ & Bignoniaceae & Archangkawm & $\begin{array}{l}\text { Indian trumpet } \\
\text { flower }\end{array}$ & Tree & Fruits & Aug-Nov & $\begin{array}{l}\text { Anti-diabetic, } \\
\text { stomach problem }\end{array}$ \\
\hline 24 & $\begin{array}{l}\text { Amophophallus } \\
\text { nepalensis (Wall.) }\end{array}$ & Araceae & Telhawng Pa & Voodoo lily & Herb & Corm & Aug-Dec & - \\
\hline
\end{tabular}



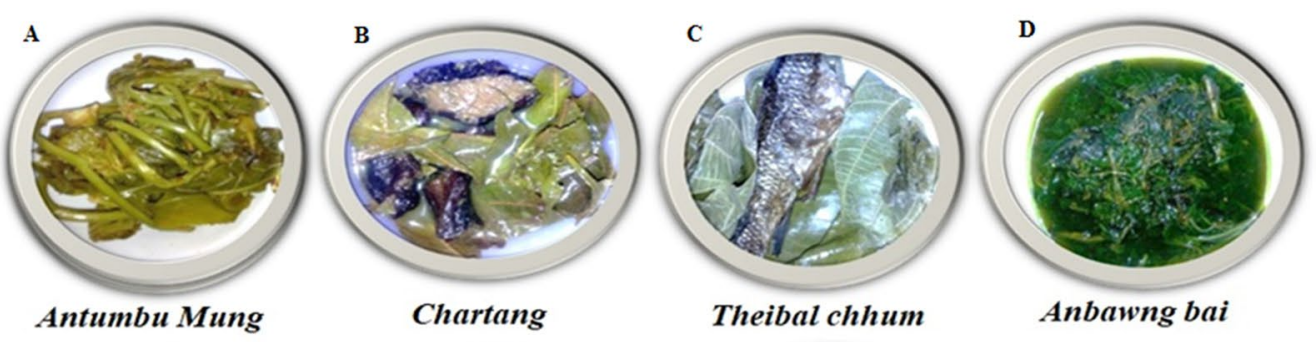

Chartang
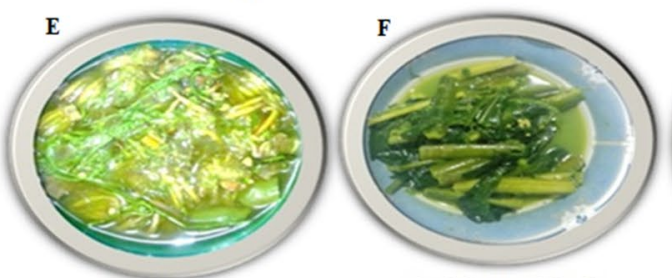

Theibal chhum

Anbawng bai
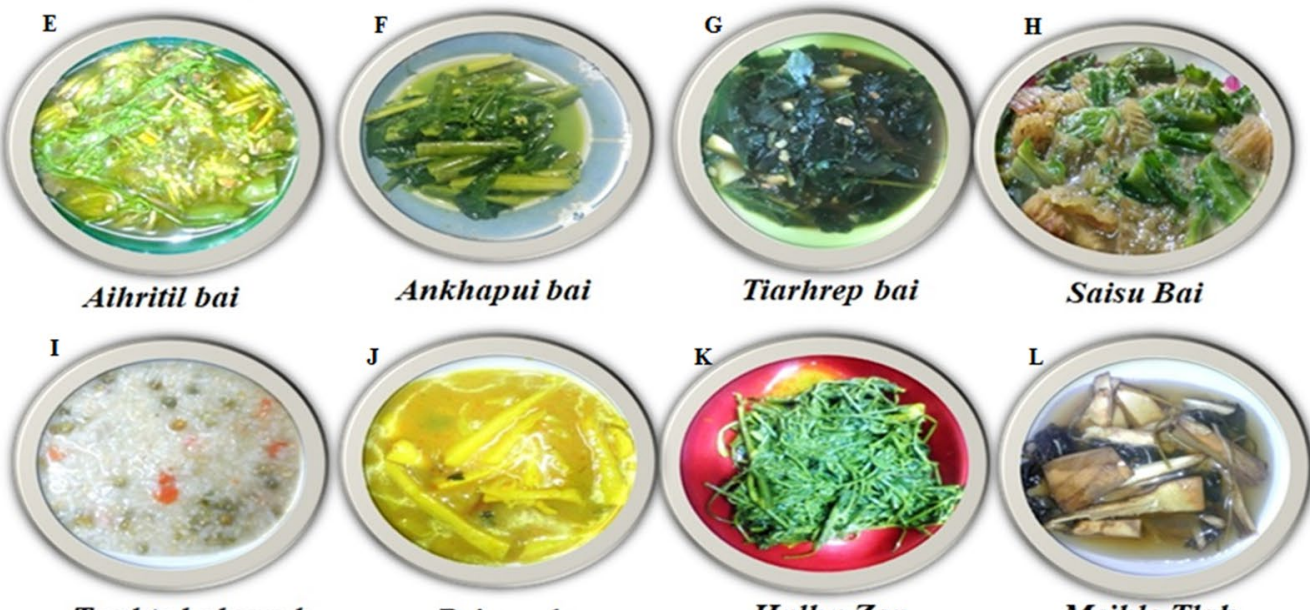

Tiarhrep bai

Saisu Bai

Tawkte buhpawk

Beipenek
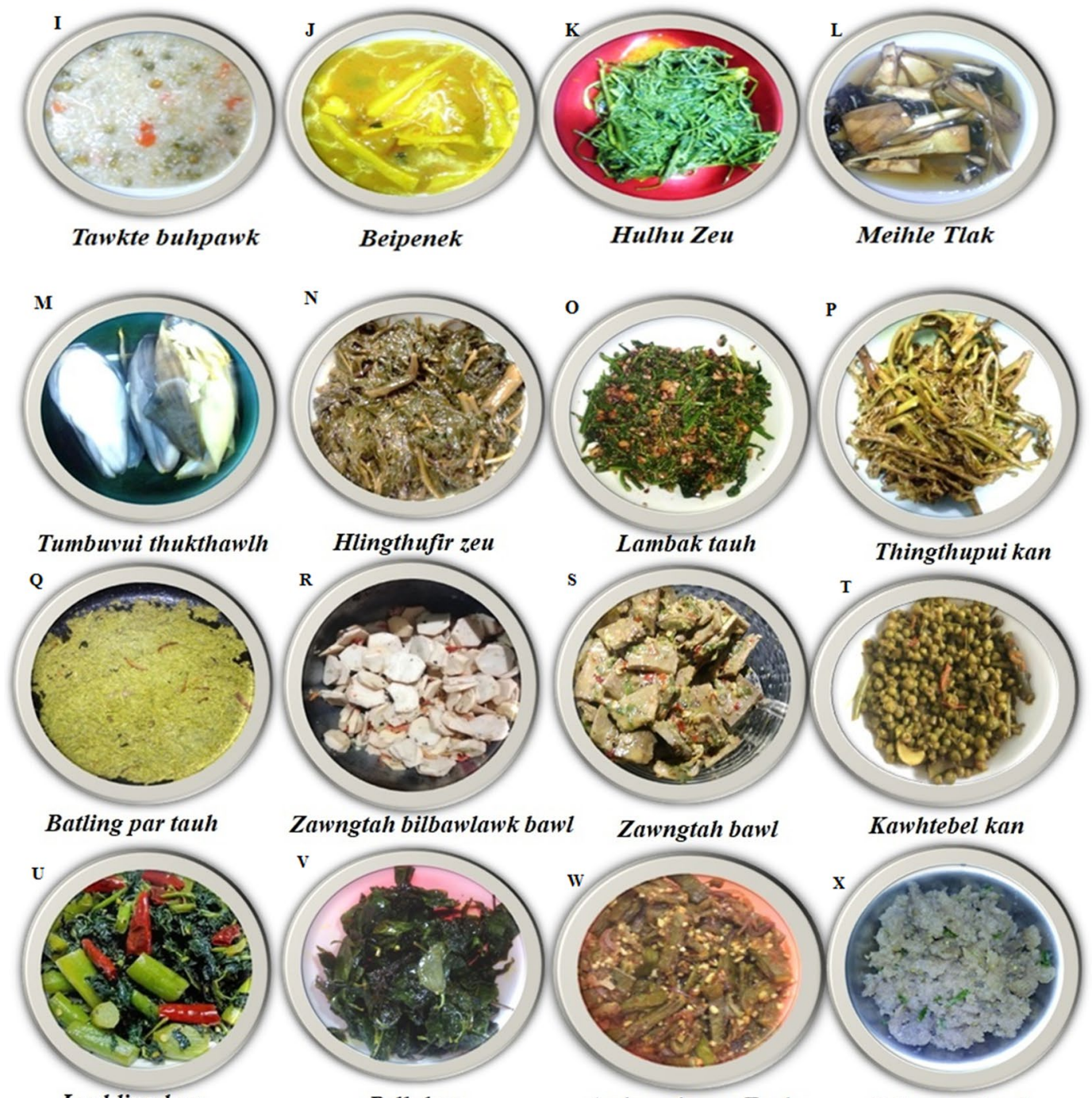

Zawngtah bilbawlawk bawl
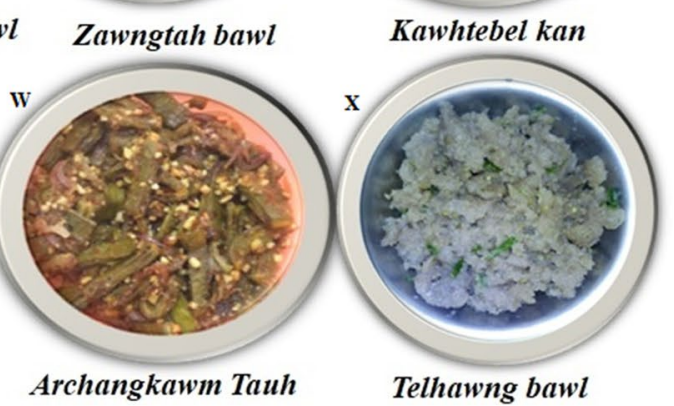

Fig. 3 Documented traditional recipes prepared by the ethnic communities of Aizawl district 
(4) Bai

Bai can be prepared by mixing different types of vegetables and is considered essential to complete the meal of two tribal groups. This study documented five methods of preparation of Bai from different vegetables such as:

(i) Anbawng Bai: The main ingredient of Anbawng bai is Fagopyrum tataricum. In this recipe, 500g of the leaves of Anbawng are chopped into small pieces and cooked in 2-3 cups of hot water or depending upon the number of vegetables used. Then, salt and an adequate amount of crushed chili are added along with three teaspoons of ash filtrate and a few drops of fermented pork fat. All the contents are stirred up well and it is ready to be served (Fig. 3D).

(ii) Aihritil Bai: It is a popular dish among Hmar tribal group. Approximately $200 \mathrm{~g}$ of the flower buds of Amomum dealbatum are cut into small pieces, and these are the main ingredients. It is then mixed with dried chili, and pre-boiled water is added. To this, an equal amount of Khanghu/khanghmuk (Sennegalia pennata) and Sihzo/sihneh (Eurya acuminata) are added with an appropriate amount of ash water. The mixture is stirred up well and foams develop. After the addition of a subsequent amount of saum, the dish is ready to be served (Fig. 3E).

(iii) Ankhapui Bai: It is a typical dish prepared from the shoot and leaves of Marsdenia maculate, mostly prepared by the two ethnic groups of the study area (Fig. 3F). For preparation, 200g of the shoot and leaves are placed over a fire for about 2 minutes to soften the skin. The skin of the shoot is peeled off and cut into small pieces and are added to preheated water, followed by the addition of salts and an appropriate amount of chingal, bekang-um (Fermented soybean), and saum. It is bitter and is often served with steamed pork.

(iv) Tiarhrep Bai: It is a typical food of Hmar and is highly preferable when the staple foods are not available. Rhynchotechum ellipticum is the main ingredient and in the preparation, approximately $300 \mathrm{~g}$ of the leaves of Rhynchotechum ellipticum are chopped into small pieces and introduced into hot water with dawlzik (Colocasia esculenta). To this, an appropriate amount of chingal is added along with salt, chili, and wild coriander. Lastly, a few amount of bekang-um is used as a seasoning (Fig. 3G).

(v) Saisu Bai: It is a prominent dish among the two ethnic groups. The main ingredient is the shoot of Ensete superbum (Fig. 3H). It is mostly prepared in combination with other vegetables. To prepare, approximately 500g of Ensete superbum shoot is cut into small pieces and added to pre-boiled water. An equal amount of leaves of cowpea (Vigna unguiculata) are added along with chili and salts. A few drops of cooking oil and baking soda are added. To elevate the taste, wild coriander and steamed pork can be added.

\section{(5) Tawkte buhpawk}

It is a typical porridge-type food of Hmar and Paihte where Solanum indicum is the main ingredient (Fig. 3I). For preparation, around $100 \mathrm{~g}$ of rice grains are first boiled in water for about $20 \mathrm{~min}$, when the rice grains become soft, an equal amount of green fruits of Solanum indicum are simply added along with salt and a pinch of baking soda. Then, the entire mixture becomes semi-solid and has a bitter taste.

\section{(6) Beipenek}

Hmar tribal group usually prepared beipenek on a special occasion and during their feast. It is a highly popular dish prepared using rice flour. There are two types of beipenek: (1) vegetarian beipenek and (2) non-vegetarian beipenek (prepared with fresh and smoked meats). This study documented Beipenek prepared from Meloccana baccifera (Fig. 3J). $1 \mathrm{~kg}$ of the young shoot of Meloccana baccifera is cut into small pieces and fried with cooking oil. Turmeric powder is added along with salt, chili, crushed onion, garlic, and wild coriander to get a pleasant fragrance and hot water is added depending upon the content of the bamboo shoot and cooked for a few minutes. At the same time, the presoaked rice is ground in the wooden mortar to get flour. This rice flour is then suspended into cold water with turmeric powder and added to the mixture to make it Nawng (gravy). It is continuously stirred until it is ready to be served. For the preparations of non-vegetarian beipenek, fresh or smoked meats are used and the same method of preparation is followed.

\section{(7) Hulhu Zeu}

Aganope thyrsifolia is the main ingredient of this recipe. To prepare hulhu zeu, $500 \mathrm{~g}$ of the tender leaves and shoots of Aganope thyrsifolia are boiledfor $1 \mathrm{~h}$. The water is discarded and added repeatedly while cooking. After the last cooking, water is removed; it is deep fried with cooking oil. Salt, onion, garlic can be added for a better taste. It is a popular dish among the two ethnic groups (Fig. 3K). 


\section{(8) Meihle Tlak}

Different types of vegetables can be used for making Tlak. This study deals with Tlak prepared from Meihle (Caryota mitis) (Fig. 3L). The tender shoot of Meihle is sliced into 1-2 inches long ( $1 \mathrm{~kg})$ and boiled for about $40 \mathrm{~min}$. When it becomes soft, smoked roselle leaves are added to enhance the taste. Salt and chilies can be added as per one's wish.

\section{(9) Tumbuvui thukthawlh}

It is a prevalent dish among the two tribal communities; the main ingredient is the inflorescence of Musa species $(\sim 1 \mathrm{~kg})$. The whole inflorescence is simply put over the fire for about one hour and the skin is peeled off to get the tender inflorescence and it is ready to serve with dried chili and salt (Fig. 3M).

\section{(10) Hlingthufir zeu}

It is also a common dish among Hmar ethnic group. Aralia dasyphylla is the main ingredient where approximately $500 \mathrm{~g}$ of the tender leaves and shoots are first boiled in water and then fried using cooking oil (Fig. 3N). Wild coriander and garlic are crushed and added at the time of serving to enhance the smell. This dish is highly preferred by Hmar community during the time of availability.

\section{(11) Lambak tauh}

The main ingredients are the whole plant of Centella asiatica and dried peanut. To prepare, a fresh plant of Centella asiatica $(\sim 200 \mathrm{~g})$ is chopped into small pieces and then first fried with cooking oil for $2 \mathrm{~min}$. Meanwhile, peanuts are fried separately and then grounded nicely. The two ingredients are mixed and then crushed onion, garlic, ginger, red chili and wild coriander are added to it (Fig. 3O).

\section{(12) Thingthupui kan}

The young shoot and leaves of Dysoxylum excelsum $(\sim 500 \mathrm{~g})$ are first boiled with water and this is the main ingredient of this recipe. The water is discarded and is simply fried in oil along with onion, dry chili, turmeric powder, and salt (Fig. 3P).

\section{(13) Batling par tauh}

This dish serves as an important food among Hmar and Paihte communities during the period of food shortage. Wendlandia budleioides flower bud is the main ingredient for this recipe (Fig. 3Q). After the flower bud $(\sim 250 \mathrm{~g})$ is boiled for several minutes, all the water is squeezed out and the flower bud is cut into small pieces. Wild corianders, red chili, king chili, turmeric, and sesame seed are crushed, and finally, all the contents are mixed together and fried in preheated oil for $5 \mathrm{~min}$.

\section{(14) Zawngtah bilbawlawk bawl}

This recipe is particularly common among Hmar although it is unfamiliar among Paihte people in the study area. It is often taken with plain rice as a side dish. The dense flower heads of Parkia timoriana (tree bean) are the main ingredients (Fig. 3R). The inflorescences $(\sim 500 \mathrm{~g})$ are rubbed off, and the skins of the flower heads are peeled off. It is sliced into a thin circular shape and is boiled for $2 \mathrm{~min}$ to reduce the bitter taste. After that, the water is discarded and the flower head is kept aside. Green king chili is put over a fire and grounded well which is again mixed with flower head and salt. Finally, one tablespoon of fermented pork fat is added while constantly stirring it and it is ready to be served with plain rice.

\section{(15) Zawngtah bawl}

The main ingredient is the fruit of Parkia timoriana. It is a popular and delicious food among the two communities but the methods of preparation are more or less different among the tribal groups. Tree beans can be eaten raw or by mixing with fermented pork. But the taste might be different because it has a mildly bitter taste if it is not boiled. To prepare, the skin of the pods $(\sim 500 \mathrm{~g})$ is peeled off by using ziahkur (sharp utensil made from iron). It is sliced into small pieces and introduced into pre-boiled water for $1 \mathrm{~min}$. All the water is removed, and the contents are mixed with 1 tablespoon of chingal, salt, and two tablespoon fermented pork fat while continuously stirring it (Fig. 3S).

\section{(16) Kawhtebel kan}

The flower buds of Trevesia palmata are taken off and transferred $(\sim 500 \mathrm{~g})$ into a pressure cooker for $10 \mathrm{~min}$, all the water is discarded, and the remaining food is kept aside. Chopped onion, garlic, and coriander are first fried with tomato for $5 \mathrm{~min}$, and finally, the flower buds are added and all the contents are mixed well and the dish is ready to be served (Fig. 3T).

\section{(17) Lenhling kan}

Lenhling kan is a typical Paihte food consumed as a main dish. The tender shoot and leaves of Amaranthus viridis $(\sim 500 \mathrm{~g})$ are finely chopped and boiled for $10 \mathrm{~min}$, the water is then discarded. The heated oil is added to the well-cooked plants, along with chopped king chili, onions, and garlic. Masala and salts are added to enhance the taste (Fig. 3U). 


\section{(18) Pelh kan}

Pelh is a local name for Gnetum gnemon. For preparation, chopped onions are fried with chili and then the leaves of pelh $(\sim 100 \mathrm{~g})$ are added by constantly stirring it in. Salt is added according to taste. The mixture after frying for 5-7 $\mathrm{min}$ is ready to be served (Fig. 3V).

\section{(19) Archangkawm Tauh}

The fruits of Oroxylum indicum $(\sim 500 \mathrm{~g})$ are placed over the fire and the skin is peeled off using ziahkur. After this, it is washed thoroughly with water, chopped into thin pieces, and kept aside. To this, fried and crushed peanut is added and mixed with onion, ginger, garlic, tomato, chili, salt, and dangpuithu to enhance the taste (Fig. 3W).

\section{(20) Telhawng bawl}

Amorphophallus nepalensis commonly called telhawng$p a$ is a typical Mizo food. Since the parts of the plants contain irritable substances causing itchiness on the throat, there is a long process to make it edible (Fig. 4). For preparation, the outermost covering of the corm is removed and sliced into small pieces, boiled in chingal for $4 \mathrm{~h}$ to reduce the irritable substance. After this, chingal is removed and the content is crushed carefully in a typical wooden mortar and pestle. The crushed corm is again boiled in an ash filtrate for 4-7 h and left to cool. After cooling, chingal is discarded, soaked in clean water by changing the water several times to remove the ash filtrate. From this preparation, $1 \mathrm{~kg}$ of telhawng is taken out and mixed with 4-5 drops of fermented pork fat, salt and chilly as per one's desire (Fig. 3X). Although the process of preparation takes timeand effort, this food is highly preferred due to its deliciousness in taste.

\section{Discussion}

In tribal areas and society, culture, tradition, and food habits cannot be separated as they are all interconnected [24]. Since rice is considered a staple food and vegetables and meat are considered as side dishes in Mizoram [11], a huge diversity of WEVs is used and consumed especially during the scarcity of agricultural crops. It is well known that WEVs have been used globally as medicines because of their nutraceutical properties [25, 26]. This survey documented 24 traditional recipes prepared from WEVs among the two ethnic groups of Mizoram, in which, a large number of WEVs were used as food medicine. The study was confined to Hmar and Paihte tribes within Aizawl District, the Northern part of Mizoram and although

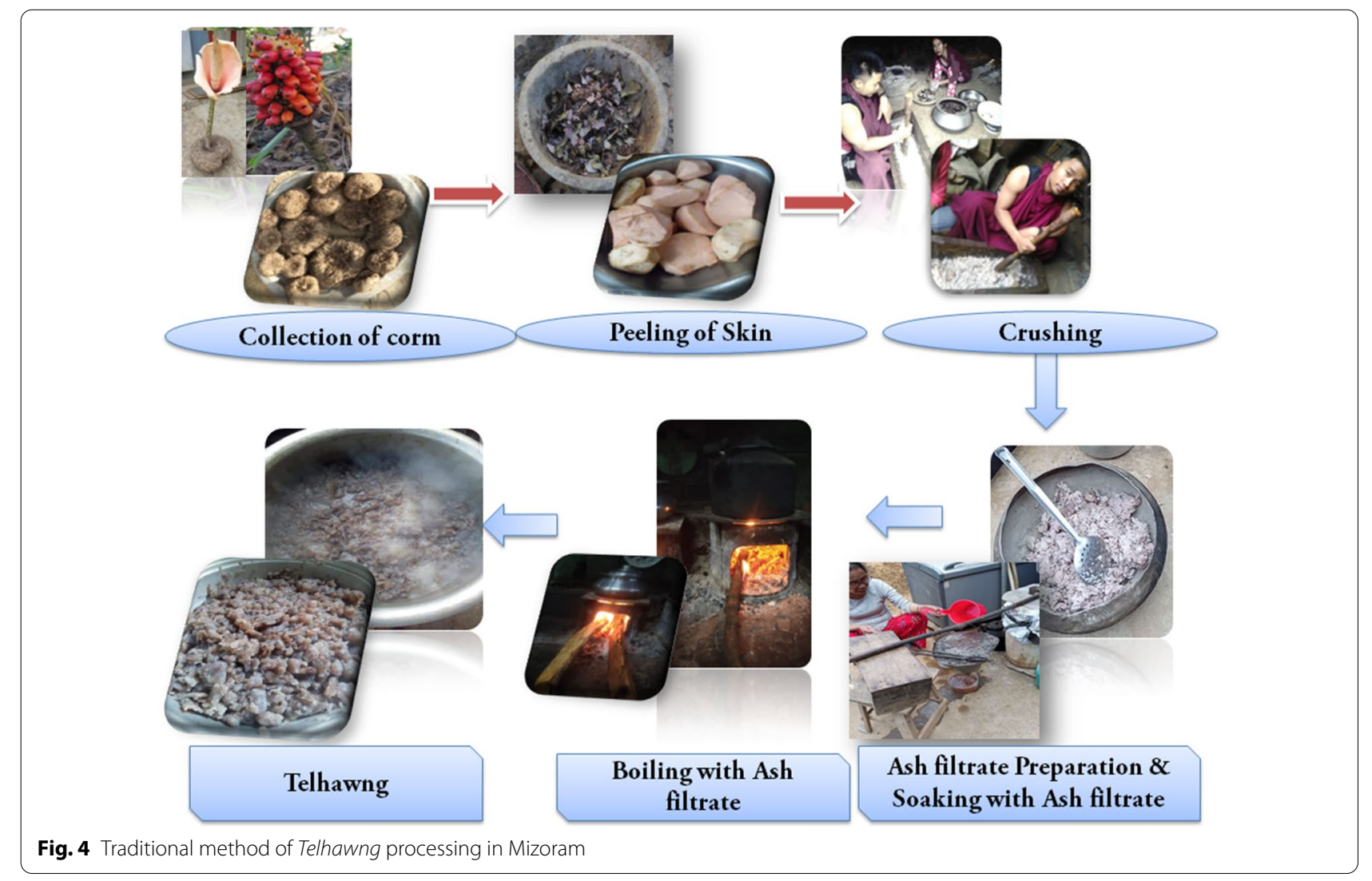


they inhabit other districts in Mizoram, the traditional recipe preparation using WEVs may slightly differ, but can be considered as representatives of the entire Mizoram for these particular tribes. Hmar and Paihte ethnic groups have more or less similar choices in affinity toward the wild edible plant consumption. This may be due to the intermixing of culture and tradition, mixed habitation, and the sharing of resources among the two ethnic communities. However, some species such as Aganope thyrsifolia, Fagopyrum tataricum, and Brassaiopsis hainla were preferably consumed by Hmar and Paihte tribe while the use of Rhynchotechum ellipticum as food by the Paihte people was not recorded during the field survey. Nevertheless, species like Oroxylum indicum had high affinity among the Paihte communities. On the other hand, there were also many species like Enseta superbum and Centella asiatica which were commonly used among the two ethnic groups for the preparations of Bai and Tauh. For instance, Hmar and Paihte tribal groups mainly reside in Mizoram adjacent to Manipur state, many species of WEVs in the present study were also used by the local tribes of Manipur, but the complex preparation of the recipe was not found [27]. Since some of the Hmar and Paihte people migrated from Manipur and resided in Mizoram, certain seasonings used for food preparation were found to be very similar. Preparation of Saum of Mizo tribe, a widely used ingredients of the recipe, was found very similar to the sathu prepared by Manipuri tribe [5] and chingal preparation was also similar to the Assamese 'Kolakhar' which used banana ashes [28] and they were decisively used for the recipes documented in the present study. The vegetables and meat cooked with rice grain also known as beipenek is a common delicious food item of the communities which were studied, this recipe is also very common among the tribal people of Manipur [5] but the method of preparation differs among the ethnic groups. Several studies have been found worldwide on the documentation of certain plants as edible vegetables including the WEVS used in the current study such as Eurya acuminata, Meloccana baccifera, Aganope thyrsifolia, Aralia dasyphylla, Amaranthus viridis, Gnetum gnemon,[8] Centella asiatica,Amomum dealbatum, Wendlandia budleioides,Dysoxylum excelsum, Marsdenia maculata [28], Musa balbisiana, Ensete superbum, Solanum anguivi, Trevesia palmata [29], Oroxylum indicum [30], Amorphopahallus nepalensis [31], Senegalia pennata [32], Ficus auriculata [33], Rhynchotechum ellipticum [34], Caryota mitis [35], Parkia timoriana, Amaranthus viridis [36]. However, to best of our knowledge, Brassaiopsis hainla has never been reported so far as edible vegetables. Furthermore, the present study gives the first report on the documentation of cuisine preparation on all the vegetables; nevertheless, there are other tribal groups such as Lai/Pawi, Lusei, Bru, Chakma and Mara in Mizoram that have their own unique traditional preparations of WEVs and needs to be explored. Taking all these into account, the diversities of traditional food products can be identified to explore their potentials in terms of commercialization [37].

\section{Conclusion}

This study presented the preparation of wild edible vegetables-based traditional foods/dishes that also have social, cultural, and economic impact on Hmar and Paihte tribes of Mizoram, Northeast India. A great diversity of WEVs was observed because of the rich natural resources in this area and the fact that the local people have knowledge about WEVs and how to prepare them. Several of them have a marketing potential and need popularization not only in other tribal groups of the states but also in other parts of the world. It is therefore important to validate the traditional food recipes to be expanded through a comprehensive socioeconomic and cultural framework. This study also presents the basic information on the necessity of conservation, sustainable utilization and preservation of local traditional knowledge on WEVs.

\section{Abbreviation \\ WEVs: Wild Edible Vegetables.}

\section{Acknowledgements}

Authors are grateful to the department of Botany, Mizoram University; department of Biotechnology and Zoology Pachhunga University College for their support; all participants for their kindness and interest in taking part in the study. Authors are also thankful to Dr. Laldinpuii, Department of English, Mizoram University, Pachhunga University College, for grammatical editing of the manuscript.

\section{Authors' contributions}

Z and RL plan the work; RL, BZ, Z and JL performed the works and all coauthors contributed to drafting and finalizing the manuscript. All authors read and approved the final manuscript.

Funding

Not Applicable.

Availability of data and materials

Not Applicable.

\section{Declarations}

Competing interests

The authors declare that there are no competing interests.

Author details

${ }^{1}$ Department of Botany, Mizoram University, Aizawl, Mizoram 796004, India. ${ }^{2}$ Department of Zoology, Mizoram University, Pachhunga University College 
Campus, Aizawl, Mizoram 796001, India. ${ }^{3}$ Department of Biotechnology/Life Sciences, Mizoram University, Pachhunga University College Campus, Aizawl, Mizoram 796001, India.

Received: 3 June 2021 Accepted: 30 September 2021 Published online: 09 October 2021

\section{References}

1. Kuhnlein HV, McDonald M, Spigelski D, et al. Gwich'in traditional food for health: Phase 1. Indigenous Peoples'food systems: the many dimensions of culture, diversity and environment for nutrition and health. Public Health Nutr. 2009;9:45-58.

2. Heywood VH. Ethnopharmacology, food production, nutrition and biodiversity conservation: towards a sustainable future for indigenous peoples. J Ethnopharmacol. 2011;137(1):1-15. https://doi.org/10.1016/j.jep.2011. 05.027 .

3. Abbasi AM, Shah MH, Khan MA. Wild edible vegetables of Lesser Himalayas. Ethnobotanical and Nutraceutical Aspects. Cham: Springer; 2005. p. 1.

4. Saikia P, Deka DC. Mineral content of some wild green leafy vegetables of North-East India. J Chem Pharm Res. 2013;5(3):117-21.

5. Singh TA, Sarangi PK, Singh NJ. Traditional process foods of the ethnic tribes of western hills of Manipur, India. Int J Curr Microbiol App Sci. 2018;7:1100-10.

6. Aberoumand A. Nutritional evaluation of edible Portulaca oleracia as plant food. Food Anal Methods. 2009;2:204. https://doi.org/10.1007/ s12161-008-9049-9.

7. Somnasang P, Moreno-Black G. Knowing, gathering and eating: knowledge and attitudes about wild food in an Isan village in Northeastern Thailand. J Ethnobiol. 2000;20(2):197-216.

8. Kar A, Bora D, Borthakur SK, Goswami NK, Saharia D. Wild edible plant resources used by the Mizos of Mizoram, India. Kathmandu University J Sci Eng Technol. 2013:9(1):106-26.

9. Liangkhaia. Mizo Chanchin (in Mizo). 4th edn. Mizo Academy of Letters, Aizawl, Mizoram. 1976.

10. Sati VP, Rinawma P. Practices of shifting cultivation and its implications in Mizoram, North-East India: a review of existing research. Nat Environ. 2014;19(2):179-87.

11. Laha, R, Lalhriatpuia. Diversity of Bryophytes in Aizawl District, Mizoram, Northeast India. 2015; 4(4):1654-7.

12. Lalthanpuii PB, Lalruatfela B, Zoramdinthara, Lalthanzara $H$. Traditional food processing techniques of the Mizo people of Northeast India. Sci Vis. 2015;15(1):39-45.

13. Thanzami $\mathrm{K}$, Lalhlenmawia $\mathrm{H}$. Ethnic fermented foods and beverages of Mizoram. In: Tamang J, editor. Ethnic fermented foods and beverages of India: science history and culture. Singapore: Springer; 2020. https://doi. org/10.1007/978-981-15-1486-9_16.

14. Skara T, Axelsson L, Stefánsson G, Ekstrand B, Hagen H. Fermented and ripened fish products in the northern European countries. J Ethn Foods. 2015;2(1):18-24. https://doi.org/10.1016/j.jef.2015.02.004

15. Tamang JP. Naturally fermented ethnic soybean foods of India. J Ethn Foods. 2015;2(1):8-17. https://doi.org/10.1016/j.jef.2015.02.003.

16. Kapoor A, Kanwar P, Gupta R. Traditional recipes of district Kangra of Himachal Pradesh. Indian j tradit knowl. 2010;9(2):282-8.

17. Devi P, Kumar P. Traditional, ethnic and fermented foods of different tribes of Manipur. Indian J Tradit Knowl. 2012;11(1):70-7.

18. Jeyaram K. Traditional fermented foods of Manipur. Indian J Tradit Knowl. 2009;8(1):115-21.

19. Deb D, Sarkar A, Debbarma B, Datta BK, Majumdar K. Wild edible plants and their utilization in traditional recipes of Tripura, Northeast India. Adv Biol Res. 2015;7(5):203-11. https://doi.org/10.5829/idosi.abr.2013.7.5. 11895.
20. Tamang JP, Thapa N. Some nonfermented ethnic foods of Sikkim in India. J Ethn Foods. 2014;1(1):29-33. https://doi.org/10.1016/j.jef.2014.11.008.

21. Singh PK, Singh KI. Traditional alcoholic beverage, Yu of Meitei communities of Manipur. Indian J Tradit Knowl. 2006;5(2):184-90.

22. Lalmuanpuii R, Zothanpuia, Zodinpuii B, Lalbiaknunga J. Phenological observations of selected wild edible vegetables from tropical and subtropical forest of Mizoram, Northeast India. Vegetos. 2020;33:409-19. https://doi.org/10.1007/s42535-020-00123-8.

23. Zothanpuia, Passari AK, Leo W, et al. Bioprospection of actinobacteria derived from freshwater sediments for their potential to produce antimicrobial compounds. Microb Cell Fact. 2018;17:68. https://doi.org/10.1186/ s12934-018-0912-0.

24. Ghosh K, Maity C, Adak A, Halder SK, Jana A, et al. Ethnic preparation of Haria, a rice-based fermented beverage, in the province of lateritic West Bengal. India Ethnobot Res Appl. 2014;12:039-49.

25. Singh B, Sultan P, Hassan QP, Gairola S, Bedi YS. Ethnobotany, traditional knowledge, and diversity of wild edible plants and fungi: a case study in the Bandipora district of Kashmir Himalaya. India J Herbs Spices Med Plants. 2016;22(3):247-78. https://doi.org/10.1080/10496475.2016.11938 33.

26. Menendez-Baceta G, Aceituno-Mata L, Reyes-García V, Tardío J, et al. The importance of cultural factors in the distribution of medicinal plant knowledge: a case study in four Basque regions. J Ethnopharmacol. 2015;161:116-27. https://doi.org/10.1016/j.jep.2014.12.007.

27. Hook I, McGee A, Henman M. Evaluation of dandelion for diuretic activity and variation in potassium content. Int J Pharmacogn. 1993;31(1):29-34. https://doi.org/10.3109/13880209309082914.

28. Konsam S, Thongam B, Handique AK. Assessment of wild leafy vegetables traditionally consumed by the ethnic communities of Manipur, northeast India. J Ethnobiol Ethnomed. 2016;12:9. https://doi.org/10.1186/ s13002-016-0080-4

29. Angami A, Gajurel PR, Rethy P, Singh B, Kalita SK. Status and potential of wild edible plants of Arunachal Pradesh. Indian J Tradit Knowl. 2006;5(4):541-50.

30. Gogoi P, Nath N. Indigenous knowledge of ethnomedicinal plants by the Assamese community in Dibrugarh District, Assam, India. J Threat Taxa. 2021;13(5):18297-312. https://doi.org/10.11609/jott.6772.13.5. 18297-18312.

31. Deb CR, Khruomo N, Paul A. Underutilized Edible Plants of Nagaland: A Survey and Documentation from Kohima, Phek and Tuensang District of Nagaland, India. Am J Plant Sci. 2019;10(01):162. https://doi.org/10.4236/ ajps.2019.101014.

32. Punchay K, Inta A, Tiansawat P, Balslev H, Wangpakapattanawong P. Traditional knowledge of wild food plants of Thai Karen and Lawa (Thailand). Genet Resour Crop Evol. 2020;67(5):1277-99.

33. Mallick SN, Sahoo T, Naik SK, Panda PC. Ethnobotanical study of wild edible food plants used by the tribals and rural populations of Odisha, India for food and livelihood security. Plant Arch. 2020;20(1):661-9.

34. Terangpi R, Engtipi U, Teron R. Utilization of less known plants, Gnetum gnemon L. and Rhynchotechum ellipticum (Dietr.) A. DC. among the Karbis, Northeast India. Int J Innov Res Sci Stud. 2013;2(5):943-9.

35. Laha R, Lalhriatpuia LR, Ralte L, Lalremruata PC. Diversity and ethnobotanical uses of wild edible fruits in Mizoram, Northeast India. Int J Pharm Bio Sci. 2018;8(2):132-42.

36. Pradhan S, Tamang JP. Ethnobiology of wild leafy vegetables of Sikkim. Indian J Tradit Knowl. 2015;14(2):290-7.

37. Kalita P, Kander CC. kolakhar-a traditional herbal soda of Assam. J Adv Pharm Res Biosci. 2014;2(5):122-3.

\section{Publisher's Note}

Springer Nature remains neutral with regard to jurisdictional claims in published maps and institutional affiliations. 